\title{
Status of irrigated soils of coastal Dev Bhumi Dwarka district of Gujarat
}

\author{
J.V. Polara* and B. M. Hadiya \\ Department of Agricultural Chemistry and Soil Science, Junagadh Agricultural University, \\ JUNAGADH (GUJARAT) INDIA (Email :jvpolara@jau.in; b.m.hadiya22@ gmail.com)
}

\begin{abstract}
In order to evaluation the fertility status of each taluka of Dev Bhumi Dwarka district viz., Kalyanpur, Dwarka, Khambhalia and Bhanvad, thirty representative surface $(0-15 \mathrm{~cm})$ soil samples were collected from cultivated farmer's field during May-2015. The chemical analysis of 120 surface samples indicates that soil were deficient with respect to available $\mathrm{P}_{2} \mathrm{O}_{5}$, whereas medium in available $\mathrm{N}$ and high in available $\mathrm{K}_{2} \mathrm{O}$ and $\mathrm{S}$ status. Among the DTPA extractable micronutrients, $\mathrm{Mn}$ and $\mathrm{Cu}$ were found high, whereas the soils were medium in Fe and $\mathrm{Zn}$. The nutrient index values were low for available $\mathrm{P}_{2} \mathrm{O}_{5}(1.43)$, medium for available $\mathrm{N}$ (1.53) and $\mathrm{S}(2.10), \mathrm{Fe}$ (1.92) and $\mathrm{Zn}(1.80)$ and high for available $\mathrm{K}_{2} \mathrm{O}(2.60), \mathrm{Mn}$ (2.66) and $\mathrm{Cu}(2.92)$ in the soils of Dev Bhumi Dwarka district.
\end{abstract}

Key Words : Available macronutrients, DTPA extractable micronutrients, Nutrient index

View Point Article : Polara, J.V. and Hadiya, B.M. (2018). Status of irrigated soils of coastal Dev Bhumi Dwarka district of Gujarat. Internat. J. agric. Sci., 14 (1) : 138-140, DOI:10.15740/HAS/IJAS/14.1/138-140.

Article History : Received : 24.06.2017; Revised : 21.11.2017; Accepted : 04.12.2017

\footnotetext{
* Author for correspondence:
} 